\title{
PEMANFAATAN KOLEKSI KHUSUS BUNG HATTA DI UPT PERPUSTAKAAN PROKLAMATOR BUNG HATTA BUKITTINGGI
}

\author{
Afifah Pebriany*), Malta Nelisa**) \\ Program Studi Informasi Perpustakaan dan Kearsipan, \\ Jurusan Bahasa dan Sastra Indonesia dan Daerah \\ Fakultas Bahasa dan Seni, Universitas Negeri Padang, Indonesia \\ email: afifahafebriany@gmail.com*)
}

Naskah diterima: 9 September ; direvisi: 12 November ; disetujui: 13 Desember 2020.

\begin{abstract}
Abstrak
Penelitian ini bertujuan untuk mendeskripsikan; (1) faktor internal, dan (2) faktor eksternal yang mempengaruhi peserta dalam memanfaatkan koleksi khusus Bung Hatta di Upt Perpustakaan Proklamasi Bung Hatta Bukittinggi. Jenis penelitian yang digunakan adalah penelitian kuantitatif, metode penelitian yang digunakan adalah metode deskriptif. Lokasi penelitian ini dilaksanakan di UPT Perpustakaan Proklamasi Bung Hatta Bukittinggi Objek penelitian adalah seorang berusia 19 tahun yang pernah mengunjungi jasa koleksi khusus bung hatta sebanyak 36 responden. Pengumpulan data dilakukan dengan menyebarkan angket langsung ke UPT Perpustakaan Proklamasi Bung Hatta Bukittinggi dengan menggunakan teknik insidental sampling. Analisis data yang digunakan adalah analisis deskriptif kuantitatif yang disajikan dalam bentuk tabel distribusi frekuensi dan persentase.
\end{abstract}

Kata Kunci: Koleksi, Perpustakaan, Bung Hatta

\begin{abstract}
This research aims to describe; (1) internal factors, and (2) external factors that influence the participants in utilizing the special collection of Bung Hatta in the Upt Library Proclamation Bung Hatta Bukittinggi. This type of research is quantitative research, the research method used is a descriptive method. The location of this research was carried out at upt Library Proclamation Bung Hatta Bukittinggi Research object is a 19-year-old who has visited bung hatta special collection service of 36 respondents. Data collection conducted by disseminating questionnaires directly to the UPT library of Bung Hatta Bukittinggi Proclamation Library using incidental sampling techniques. The data analysis used is a quantitative deksriptive analysis presented in the form of a frequency and percentage distribution table.
\end{abstract}

Keywords: Collection, Library, Bung Hatta

\section{PENDAHULUAN}

Perpustakaan merupakan pusat sumber informasi, perpustakaan dituntut menyediakan koleksi yang sesuai dengan lingkungan, perkembangan dan kebutuhan pengguna, perpustakaan juga sebagai sarana dalam memenuhi kebutuhan informasi, karena kebutuhan informasi yang berbeda-beda terhadap berbagi faktor maka tumbuhlah berbagai jenis koleksi. Adapun berbagai jenis koleksi pada saat ini adalah koleksi umum, koleksi anak, koleksi referensi dan koleksi khusus. Koleksi merupakan komponen penting yang menjadi penggerak kegiatan perpustakaan. Dalam upaya memberikan layanan yang prima 
dibutuhkan koleksi-koleksi yang dapat memenuhi kebutuhan informasi pemustaka.

UPT Perpustakaan Proklamator Bung Hatta merupakan salah satu Perpustakaan Nasional Indonesia yang terletak di kota Bukittinggi. Di Perpustakaan Proklamator Bung Hatta terdapat Ruang Khusus Bung Hatta (RKBH), sebuah ruang baca yang ada di UPT Perpustakaan Proklamator Bung Hatta yang memiliki koleksi khusus terkait Tokoh Proklamator Bung Hatta.

Koleksi khusus Bung Hatta adalah koleksi yang terkait dengan tokoh proklamator Bung Hatta, cerita sejarah dan berbagai aspek lainya, dalam bentuk digital, monograf, dan bulettin, bedasarkan pengamatan yang dilakukan, koleksi khusus Bung Hatta yang ada di UPT Perpustakaan Proklamator Bung Hatta sebanyak 217 eksemplar 202 judul, buku-buku di ruang khusus Bung Hatta di simpan dilemari khusus, tidak hanya untuk memberikan tampilan yang berbeda dengan koleksi umum, hal ini juga berguna supaya koleksi tersebut tetap terjaga

Penulis tertarik untuk mengangkat judul pemanfaatan koleksi khusus Bung Hatta, yang melatar belakangi penulis ialah koleksi khusus Bung Hatta merupakan koleksi-koleksi yang terkait dengan sosok tokoh proklamator Bung Hatta sebagian besar koleksi tersebut merupakan karya-karya Bung Hatta sendiri dan ada beberapa karya penulis lainya, koleksi khusus Bung Hatta ada berbagi jenis seperti dalam bentuk digital, monograf, dan audio, video bedasarkan pengamatan yang dilakukan, koleksi khusus Bung Hatta yang ada di UPT Perpustakaan Proklamator Bung Hatta sebanyak 217 eksemplar 202 judul, buku-buku di ruang khusus Bung Hatta di simpan dilemari khusus, tidak hanya untuk memberikan tampilan yang berbeda dengan koleksi umum, hal ini juga berguna supaya koleksi tersebut tetap terjaga, beberapa koleksi khusus Bung Hatta kertasnya mulai rapuh dimakan rayap, bahan pustaka yang terbuat dari kertas mudah rusak, kekuatan kertas semakin lama semakin menurun kemudian kertas akan berubah warna menjadi kekuningan yang mengakibatkan kertas menjadi rapuh sehingga perlu perhatian khusus terhadapat koleksi tersebut.

Kemudian dilihat dari statistik pengunjung perpustakaan, jumlah kunjingan pemustaka yang memanfaatkan koleksi khusus tent Bung Hatta tidak banyak, dari data statistik kunjungan perpustakaan, kunjungan pemustaka pada bula Juni-July 2020 rata-rata 10.923 pengunjung, ternyata hanya 10 pemustaka yang mengunjungi ruang khusus koleksi Bung Hatta. Melihat dari pengamatan yang dilakukan jumlah frekuensi kunjungan pemustaka cukup banyak akan tetapi tingkat frekuensi kunjungan koleksi khsusus Bung Hatta sedikit, menurut hasil wawancara dengan pustakawan RKBH (Ruang Koleksi Khusus Bung Hatta) hal ini disebabkan karena ketidak tahuan pemustaka terhadap layanan koleksi khusus Bung Hatta ini

Faktor lain yang menyebabkan masyarakat kurang memanfaatkan koleksi khusus disebabkan karena selama ini petugas perpustakaan belum cukup maksimal dalam melakukan promosi sehingga banyak pemustaka tidak tau dengan keberadaan koleksi khusus Bung Hatta yang ada di perpustakaan hal inilah yang membuat pemustaka jarang memanfaatkan koleksi khusus Bung Hatta. Hasil wawancara dengan pustakawan RKBH (Ruang Koleksi Khusus Bung Hatta) promosi koleksi khusus Bung Hatta dilakukan pada saat hari-hari tertentu saja seperti hari peringatan berdirinya perpustkaan dan hari peringatan kelahiran bapak Bung Hatta

Adanya kebutuhan informasi yang berasal dari faktor internal dan eksternal sehingga mendorong pemustaka untuk memanfaatkan koleksi khusus Bung Hatta. Pemanfaatan koleksi yang dilakukan pemustaka membuktikan perpustakaan masih dibutuhkan untuk memenuhi kebutuhan informasi, melalui perpustakaan kita dapat memperoleh informasi yang dibutuhkan, pemanfaatan koleksi sangat berpengaruh penting terhadap perpustakaan dengan banyaknya koleksi perpustakaan dimanfaatkan oleh pemustaka dapat menjadi tolak ukur keberhasilan sebuah perpustakaan dalam mencapi tujuannya.

\section{METODE PENELITIAN}

Jenis penelitian digunakan adalah deskriptif. Penelitian deskriptif dengan pendekatan kuantitatif. Menurut Arikunto (2010) menyatakan bahwa penelitian deskriptif ialah penelitian yang termasuk informasi mengenai status gejala yang ada, yaitu gejala apa yang ada disaat melakukan penelitian.

Lokasi yang digunakan dalam penelitian adalah UPT Perpstakaan Proklamator Bung Hatta Bukittinggi. Lokasi tersebut dipilih sebagai lokasi dan sumber penelitian karena merupakan perpustakaan yang menyediakan koleksi khusus tentang tokoh Proklamator Bung Hatta, Subjek dalam penelitian ini yaitu pemustaka yang memanfaatkan koleksi khusus Bung Hatta. 
HASIL DAN PEMBAHASAN

Pemanfaatan koleksi khusus Bung Hatta oleh Pemustaka UPT Perpustakaan Proklamator Bung Hatta Bukittinggi

\section{Pemustaka Memanfaatkan Koleksi Khusus Bung Hatta}

Dalam pemanfaatankoleksi khusus Bung Hatta bedasarkan hasil pengolahan data dapat diketahui pemustaka memanfaatkan koleksi khusus Bung Hatta dengan membaca koleksi khusus Bung Hatta di ruang koleksi khusus hal ini agar dapat memenuhi kebutuhan informasi pemustaka, koleksi hanya dapat dibaca diruang koleksi khusus dan tidak boleh dibawa pulang atau dipinjam oleh pemustaka dikarenakan koleksi khusus Bung Hatta merupakan koleksi langka. Menurut bapak Erni Zulfan selaku pustakawan ruang koleksi khusus Bung Hatta:

Koleksi khusus Bung Hatta adalah koleksi utama di UPT Perpustakaan Proklamator Bung Hatta koleksi-koleksi disini tidak dapat dipinjam oleh pemustaka hanya bisa dibaca di ruang ini saja, jika ada pemustaka yang sangat membutuhkan informasi pemustaka dapat meminta tolong kepada pustakawan untuk menfotokopikan koleksi, perpustakaan menfasilitasinya, akan tetapi tidak semuanya dapat difotokopi.

Dari pernyataan pustakawan di atas dapat peneliti simpulkan bahwa koleksi khusus Bung Hatta hanya dapat dimanfaatkan pemustaka dengan cara membaca koleksi di ruang koleksi khusus saja berati koleksi tidak dapat dibawa keluar ruang koleksi khusus seperti ruang baca umum bahkan koleksi khusus juga tidak dapat dipinjam oleh pemustaka akan tetapi jika pemustaka membutuhkan informasi yang ada pada koleksi pemustaka dapat mefotokopi koleksi koleksi.

\section{Jenis Koleksi Khusus Bung Hatta yang Dimanfaatkan Oleh Pemustaka}

Koleksi merupakan komponen penting bagi perpustakaan, Prastowo (2012), jenis koleksi perpustakaan dikelompokkan sebagai berikut: (a) koleksi buku; (b) koleksi cetakan bahan bukan buku; (c) koleksi alat peraga; (d) koleksi pandang dengar. di UPT perpustakaan Proklamator Bung Hatta menyediakan beberapa jenis koleksi Khusus Bung Hatta yang dapat dimanfaatkan oleh pemustaka seperti koleksi tercetak contohnya buku sejarah Bung Hatta, Biografi Bung Hatta, karya Bung Hatta serta kumpulan pidato Bung Hatta, selanjutnya koleksi non cetak contohnya film pendek vidio tentang Bung Hatta dan rekaman pidato-pidato Bung
Hatta. Jumlah koleksi khusus Bung Hatta yang disediakan oleh perpustkaan yaitu sebanyak 201 koleksi tercetak dan 16 koleksi noncetak, semua koleksi disusun dilemari sesuai dengan nomor klasifikasinya. Ketersedian koleksi dijelaskan oleh bapak Erni Zulfan selaku pustakawan ruang koleksi Khusus Bung Hatta

Bapak Erni Zulfan mengatakan saat ini UPT Perpustakaan Proklamator Bung Hatta memiliki koleksi khusus Bung Hatta sebanyak 217 eksemplar, 201 koleksi tercetak dan 16 koleksi noncetak seperti audio dan vidio, koleksi Bung Hatta yang tercetak sebagian besarnya merupakan karya Bung Hatta sendiri dan ada juga dari penulis lain, koleksi karya Bung Hatta sendiri didapatkan perpustakaan dari keluarga Bung Hatta sedangkan koleksi yang bukan karya Bung Hatta merupakan sumbangan dari penulis dan dibeli, koleksi noncatak Bung Hatta itu merupakan rekaman audio dan vidio pidato bapak Bung Hatta.

Bedasarkan hasil penelitian koleksi yang sering dimanfaatkan oleh pemustaka yaitu koleksi tercetak dikarenakan lebih mudah untuk dimanfaatkan oleh pemustaka seperti tidak menggunkan alat bantu lain dalam pemanfaatannya serta koleksi tercetak yang disediakan oleh perpustakaan lebih lengkap dibandingan dengan jenis koleksi lainya.

\section{Layanan Pustakawan Ruang Koleksi Khusus Bung Hatta \\ Seorang pustakaawan yang ada} diperpustakaan harus mampu dalam berkomunikasi yang baik dengan pemustaka, adapun keterampilan yang harus dimiliki pustakawan menurut IFLA (2006) yaitu kemampuan berkomunikasi, kemampuan memahami kebutuhan pengguna, kemampuan bekerja sama, memiliki keterampilan informasi, keterampilan mengenai materi perpustakaan, keterampilan tentang bacaan anak termasuk media serta kebudayaan, kemampuan manajemen, dan memiliki kemampuan di bidang teknologi informasi yang dapat membantu pemustaka dalam menemukan informasi.

Untuk Mengetahui layanan pustakawan ruang koleksi khusus Bung Hatta UPT Perpustakan Proklamator Bung Hatta Bukittinggi peneliti melakukan wawancara dengan salah satu pemustaka UPT Perpustakan Proklamator Bung Hatta Bukittinggi yang pernah memanfaatkan koleksi khusus Bung Hatta, hal ini dilakukan untuk mencari tahu mengenai sikap dan keterampilan pustakawan yang bertugas di 
ruang koleksi khusus Bung Hatta seperti yang di ungkap oleh Tissy selaku pemustaka.

Tissy menyatakan pustakawan ruang koleksi khusus Bung Hatta sangat ramah kepada pemustaka, bahkan pemustaka dipersilakan untuk memakan permen yang disediakan oleh perpustakaan untuk bisa dinikmati oleh pemustakaan, sehingga berkunjung ke ruang koleksi khusus ini nyaman.

Dari hasil wawancara diatas dapat peneliti pahami bahwa keterampilan pustakawan juga menentukan tingkat pemanfaatan dan juga nilai kunjungan oleh pemustaka, pustakawan yang ramah dengan pemustaka dan mampu berkomunikasi dengan baik dengan pemustaka cenderung diminati oleh pemustaka sehingga membuat pemustaka nyaman untuk mencari informasi.

\section{Faktor Internal Pemanfaatan Koleksi Khusus Bung Hatta}

1. Kebutuhan Pengguna

Setiap individu memiliki kebutuhan informasi yang berbeda-beda dalam memenuhi kebutuhan informasinya.menurut Tan dalam Yusup (2010: 91) pemenuhan informasi yang didapat di perpustakaan terbagi atas 5 kategori yaitu kebutuahan kognitif, efektif, integrasi personal, integrasi sosial, dan kebutuhan berhayal.

Tabel 1.Pemustaka Memanfaat koleksi khusus Bung Hatta untuk menambah informasi

\begin{tabular}{lcc}
\hline \multicolumn{1}{c}{ Kriteria Jawaban } & F & $\mathbf{\%}$ \\
\hline Sangat setuju & 14 & $38.89 \%$ \\
Setuju & 17 & $47.22 \%$ \\
Tidak setuju & 4 & $11.11 \%$ \\
Sangat tidak setuju & 1 & $2.78 \%$ \\
\hline \multicolumn{1}{c}{ Jumlah } & $\mathbf{3 6}$ & $\mathbf{1 0 0 \%}$ \\
\hline
\end{tabular}

Jadi dapat disimpulkan bahwa yang mempengaruhi pemustaka memanfaatkan koleksi khusus Bung Hatta yaitu karena adanya kebutuhan untuk menambah informasi dan pengetahuan.Hal ini sesuai dengan kebutuhan seseorang terkait pemenuhan informasi yaitu kebutuhan kognitif. Hal ini sesuai dengan pendapat Yusup (2010:91) Kebutuhan kognitif berkaitan erat dengan kebutuhan untuk memperkuat atau menambah informasi, pengetahuan, dan pemahaman seseorang akan lingkungannya.
Tabel 2.Pemustaka Memanfaatkan Koleksi Khusus Bung Hatta Untuk Memenuhi Kebutuhan Hiburan dan Rekreasi

\begin{tabular}{lcc}
\hline \multicolumn{1}{c}{ Kriteria Jawaban } & F & $\mathbf{\%}$ \\
\hline Sangat setuju & 10 & $27.78 \%$ \\
Setuju & 17 & $47.22 \%$ \\
Tidak setuju & 8 & $22.22 \%$ \\
Sangat tidak setuju & 1 & $2.78 \%$ \\
\hline \multicolumn{1}{c}{ Jumlah } & $\mathbf{3 6}$ & $\mathbf{1 0 0 \%}$ \\
\hline
\end{tabular}

Bedasarkan hasil pada pengolahan data bahwa pemustaka memanfaatkan koleksi khusus Bung Hatta untuk memenuhi kebutuhan hiburan dan rekreasi. Hal ini sesuai dengan tujuan pemustaka untuk memenuhi kebutuhan hiburan dan rekreasi yaitu memenuhi kebutuhan afektif. Istiawan (2014) kebutuhan afektif ialah kebutuhan yang berhubungan dengan pengalaman estetik, kesenangan dan pengalaman emosional.

Tabel 3.Pemustaka Memanfaatkan Koleksi Khusus Bung Hatta Untuk Mendapatkan Pengakuan Dari Orang Lain

\begin{tabular}{lcc}
\hline \multicolumn{1}{c}{ Kriteria Jawaban } & F & $\mathbf{\%}$ \\
\hline Sangat setuju & 5 & $13.89 \%$ \\
Setuju & 11 & $30.56 \%$ \\
Tidak setuju & 11 & $30.56 \%$ \\
Sangat tidak setuju & 9 & $25 \%$ \\
\hline \multicolumn{1}{c}{ Jumlah } & $\mathbf{3 6}$ & $\mathbf{1 0 0 \%}$ \\
\hline
\end{tabular}

Dari pengolahan data bahwa pemustaka tidak memanfaatkan koleksi khusus Bung Hatta untuk mendapatkan pengakuan dari orang lain jadi koleksi khusus Bung Hatta tidak dimanfaatkan pemustaka untuk memenuhi kebutuhan integrasi personal mereka. Jadi koleksi khsusus Bung Hatta tidak dimanfaaatkan pemustaka untuk memenuhi kebutuhan integrasi personal. Yusup (2013) Kebutuhan integrasi personal sering dikaitkan dengan penguatan kredibilitas, kepercayaan, stabilitas, dan status individu. Kebutuhan-kebutuhan ini berasal dari hasrat seseorang untuk mencari harga diri.

\section{Tabel 4.Pemustaka Memanfaatkan koleksi khusus bung hatta untuk memotifasi diri}

\begin{tabular}{lcc}
\hline \multicolumn{1}{c}{ Kriteria Jawaban } & F & $\mathbf{\%}$ \\
\hline Sangat setuju & 7 & $19.44 \%$ \\
Setuju & 17 & $47.22 \%$ \\
Tidak setuju & 10 & $27.78 \%$ \\
Sangat tidak setuju & 2 & $5.56 \%$ \\
\hline \multicolumn{1}{c}{ Jumlah } & $\mathbf{3 6}$ & $\mathbf{1 0 0 \%}$ \\
\hline
\end{tabular}

Dapat disimpulkan bahwa pemustaka memanfaatkan koleksi khusus Bung Hatta untuk 
mengembangkan memotivasi diri jadi koleksi khusus Bung Hatta dimanfaatkan pemustaka untuk memenuhi kebutuhan integrasi sosial. Yusup (2013) Kebutuhan integrasi sosial ini dikaitkan dengan penguatan hubungan dengan keluarga, teman, dan orang lain di dunia. Hal ini sesuai dengan kodrat dasar manusia sebagai makhluk sosial, yang selalu ingin bersosial dalam kehidupannya.Berkaitan dengan kebutuhan ini perpustakaan berupya menyediakan koleksi tentang motivasi.

Tabel 5.Pemustaka Memanfaatkan Koleksi Khusus Bung Hatta Untuk Mengembangkan Potensi Diri

\begin{tabular}{lcc}
\hline \multicolumn{1}{c}{ Kriteria Jawaban } & F & $\mathbf{~ \%}$ \\
\hline Sangat setuju & 8 & $19.44 \%$ \\
Setuju & 22 & $47.22 \%$ \\
Tidak setuju & 4 & $27.78 \%$ \\
Sangat tidak setuju & 2 & $5.56 \%$ \\
\hline \multicolumn{1}{c}{ Jumlah } & $\mathbf{3 6}$ & $\mathbf{1 0 0 \%}$ \\
\hline
\end{tabular}

Jadi dapat disimpulkan bahwa pemustaka memanfaatkan koleksi khusus Bung Hatta untuk mengembangkan potensi diri jadi koleksi khusus Bung Hatta dimanfaatkan pemustaka untuk memenuhi kebutuhan berkhayal.menurut Istiawan (2014) kebutuhan untuk menghindari diri dari tekanan, mengalihkan perhatian dan dorongan untuk mencari hiburan

\section{Motif Pengguna}

Tabel 6.Pemustaka Memanfaatkan Koleksi Khusus Bung Hatta Untuk Memenuhi Kebutuhan Informasi

\begin{tabular}{lcc}
\hline \multicolumn{1}{c}{ Kriteria Jawaban } & F & \% \\
\hline Sangat setuju & 7 & $19.44 \%$ \\
Setuju & 20 & $55.56 \%$ \\
Tidak setuju & 9 & $9 \%$ \\
Sangat tidak setuju & 0 & - \\
\hline \multicolumn{1}{c}{ Jumlah } & $\mathbf{3 6}$ & $\mathbf{1 0 0 \%}$ \\
\hline
\end{tabular}

Jadi dapat disimpulkan bahwa pemustaka yang memiliki motif memanfaatkan koleksi khusus Bung Hatta untuk memenuhi kebutuhan informasi jadi pemustaka memiliki motif untuk memenuhi kebutuhannya dalam memanfaatkan koleksi khusus Bung Hatta, sejalan dengan pendapat Nur (2012:83) motif adalah dorongan yang sudah terikat pada suatu tujuan. Menurut penulis dalam penelitian ini ada suatu dorongan pemustaka untuk memanfaatkan koleksi khusus Bung Hatta yaitu dorongan untuk memenuhi kebutuhan informasi.
Tabel 7.Pemustaka Memanfaatkan Koleksi Khusus Bung Hatta Untuk Menyelesaikan Tugas Atau Penelitian

\begin{tabular}{lcc}
\hline \multicolumn{1}{c}{ Kriteria Jawaban } & F & $\mathbf{~ \%}$ \\
\hline Sangat setuju & 23 & $63.89 \%$ \\
Setuju & 12 & $33.33 \%$ \\
Tidak setuju & 1 & $2.78 \%$ \\
Sangat tidak setuju & 0 & $0 \%$ \\
\hline \multicolumn{1}{c}{ Jumlah } & $\mathbf{3 6}$ & $\mathbf{1 0 0 \%}$ \\
\hline
\end{tabular}

Menurut data pada tabel 8 diketahui bahwa responden yang memiliki motif memanfaatkan koleksi khusus Bung Hatta untuk menyelesaikan tugas atau penelitian sebanayak 23 orang responden (63.89\%) sangat setuju, 12 orang responden $(33.33 \%)$ setuju, sementara 1 orang responden (2.78\%) tidak setuju dan tidak ada responden yang sangat tidak setuju. Menurut hasil data bahwa pemustaka yang memiliki motif memanfaatkan koleksi khusus Bung Hatta untuk menyelesaikan tugas atau penelitian jadi pemustaka memiliki motif untuk memenuhi suatu dorongan dalam memanfaatkan koleksi khusus Bung Hatta.alasan pemustaka memanfaatkan koleksi khusus berbeda-beda seperti mengerjakan tugas kelompok, melakukan penelitian, mencari dan menggunakan informasi, dan lainnya.

\section{Tabel 8.Pemustaka Memanfaatkan koleksi khusus Bung Hatta untuk menambah wawasan dan pengetahuan}

\begin{tabular}{|c|c|c|}
\hline Kriteria Jawaban & $\mathbf{F}$ & $\%$ \\
\hline Sangat setuju & 8 & $22.22 \%$ \\
\hline Setuju & 19 & $52.78 \%$ \\
\hline Tidak setuju & 8 & $22.22 \%$ \\
\hline Sangat tidak setuju & 1 & $2.78 \%$ \\
\hline Jumlah & 36 & $100 \%$ \\
\hline
\end{tabular}
pengguna, pemanfaatan koleksi perpustakaan dipengaruhi oleh faktor internal yang meliputi motif pengguna, menurut pengolahan data alasan atau motif pemustaka memanfaatkan koleksi khusus Bung Hatta yaitu karena adanya dorongan kebutuhan yang perlu dipenuhi.Alasan pemustaka memanfaatkan koleksi khusus Bung Hatta ialah untuk menyelesaikan tugas atau penelitian. Motif merupakan suatu dorongan kebutuhan diri seseorang, 
Tabel 9. Pemustaka Koleksi Khusus Bung Hatta Untuk Membaca Koleksi Khusus Bung Hatta

\begin{tabular}{lcc}
\hline \multicolumn{1}{c}{ Kriteria Jawaban } & F & \% \\
\hline Sangat setuju & 14 & $38.89 \%$ \\
Setuju & 20 & $55.56 \%$ \\
Tidak setuju & 2 & $5.56 \%$ \\
Sangat tidak setuju & 0 & - \\
\hline \multicolumn{1}{c}{ Jumlah } & $\mathbf{3 6}$ & $\mathbf{1 0 0 \%}$ \\
\hline
\end{tabular}

Menurut data pada tabel 10 diketahui bahwa responden yang memiliki minat mengunjungi UPT perpustakaan proklamator Bung Hatta untuk membaca koleksi khusus Bung Hatta 14 orang responden (38.89\%) sangat setuju, 20 orang responden $(55.56 \%)$ setuju sementara yang tidak setuju 2 orang responden (5.56\%) dan tidak ada responden yang tidak setuju. Dapat disimpulkan bahwa pemustaka yang memiliki minat atau keinginan memanfaatkan koleksi khusus Bung Hatta untuk untuk membaca koleksi khusus agar dapat memenuhi kebutuhan informasi serta minat baca pemustaka itu sendiri.

\begin{tabular}{|c|c|c|}
\hline Kriteria Jawaban & $\mathbf{F}$ & $\%$ \\
\hline Sangat setuju & 6 & $16.67 \%$ \\
\hline Setuju & 2 & $5.56 \%$ \\
\hline Tidak setuju & 17 & $47.22 \%$ \\
\hline Sangat tidak setuju & 11 & $33.33 \%$ \\
\hline Jumlah & 36 & $100 \%$ \\
\hline
\end{tabular}

Menurut data pada tabel 11 diketahui bahwa responden yang memiliki minat mendapatkan informasi dengan memanfaatkan koleksi khusus noncetak Bung Hatta sebanyak 6 orang responden $(16,67 \%)$ sangat setuju, 2 orang responden (5.56\%) setuju dan yang tidak setuju 17 orang responden (47.22\%) dan 11 orang responden (33.33\%) yang sangat tidak setuju. Dapat disimpulkan bahwa responden tidak memiliki minat atau keinginan mendapatkan informasi dengan memanfaatkan koleksi khusus noncetak Bung Hatta untuk memenuhi kebutuhan informasi pemustaka.
Tabel 11.Pemustaka Mendapatkan Informasi Dengan Cara Memfoto Atau Menfotokopi Koleksi Khusus Bung Hatta

\begin{tabular}{lcc}
\hline Kriteria Jawaban & F & \% \\
\hline Sangat setuju & 7 & $19.44 \%$ \\
Setuju & 15 & $41.67 \%$ \\
Tidak setuju & 10 & $27.78 \%$ \\
Sangat tidak setuju & 4 & $11.11 \%$ \\
\hline \multicolumn{1}{c}{ Jumlah } & $\mathbf{3 6}$ & $\mathbf{1 0 0 \%}$ \\
\hline
\end{tabular}

Bedasarkan pengolahan data minat pengguna, pemanfaatan koleksi perpustakaan dipengaruhi oleh faktor internal yang meliputi minat pengguna, menurut pengolahan data minat atau keinginan pemustaka memanfaatkan koleksi khusus Bung Hatta yaitu karena adanya keinginan untuk membaca koleksi khusus Bung Hatta. Minat dapat diartikan sebagai "kecenderungan hati yang tinggi terhadap sesuatu, gairah dan keinginan." Dalam kaitannya dengan koleksi perpustakaan minat dapat diartikan sebagai keinginan atau kecenderungan hati seorang pemustaka untuk menggunakan koleksi yang ada pada perpustakaan guna memenuhi kebutuhan informasi.

\section{Faktor Eksternal Pemanfaatan Koleksi Khusus Bung Hatta}

\section{Kelengkapan Koleksi Perpustakaan}

Kelengkapan koleksi adalah ketersedian koleksi serta penyusunan dan penataan koleksi berdasarkan klasifikasi untuk mempermudah pemustaka dalam mencari, menemukan, dan mengumpulkan informasi yang di butuhkan. Kelengkapan koleksi di uraikan kedalam itemitem pertanyaan: kesesuaian koleksi, ketersediaan koleksi, kemutakhiran koleksi.

Tabel 12. Koleksi Khusus Bung Hatta Yang Disediakan Perpustakaan Sesuai Dengan Kebutuhan Pengguna

\begin{tabular}{lcc}
\hline \multicolumn{1}{c}{ Kriteria Jawaban } & F & \% \\
\hline Sangat setuju & 7 & $19.44 \%$ \\
Setuju & 16 & $44.44 \%$ \\
Tidak setuju & 10 & $27.78 \%$ \\
Sangat tidak setuju & 3 & $8.33 \%$ \\
\hline \multicolumn{1}{c}{ Jumlah } & $\mathbf{3 6}$ & $\mathbf{1 0 0 \%}$ \\
\hline
\end{tabular}

Menurut data tabel 13 jawaban responden mengenai kesesuaian koleksi perpustakaan dengan kebutuhan pengguna bedasarkan data yang diperoleh presentasenya sangat setuju 7 orang responden (19.44\%), setuju 16 orang responden (44.44\%) dan tidak setuju 10 orang 
responden (27.78\%) serta sangat tidak setuju 3 orang responden (8.33\%). Kelengkapan koleksi atau ketersediaaan koleksi khusus Bung Hatta yang di perpustakaan sudah sesuai dengan kebutuhan pengguna adanya kesesuai antara ketersedian koleksi pada perpustakaan dengan informasi yang dibutuhkan pengguna.hal ini sejalan dengan teori Sutarno (2006:75) koleksi perpustakaan hendaknya disesuaikan dengan kebutuhan pengguna perpustakaan.

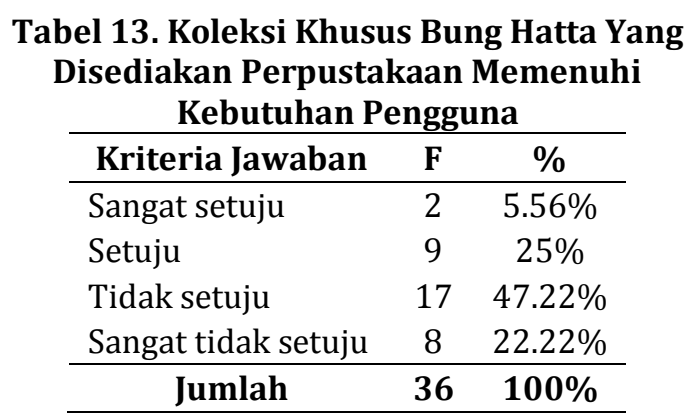

Dapat disimpulkan bahwa koleksi khusus Bung yang disediakan oleh perpustakaan belum dapat memenuhi kebutuhan pengguna. Koleksi yang disediakan perpustkaan sudah sesuai dengan yang pemustaka butuhkan namun informasi yang mereka dapatkan masih kurang atau belum cukup untuk memenuhi kebutuhan informasi pemustaka.Hampir setengah responden (47.22\%) merasa koleksi yang di sediakan perpustakaan belum cukup untuk memenuhi kebutuan informasi mereka.

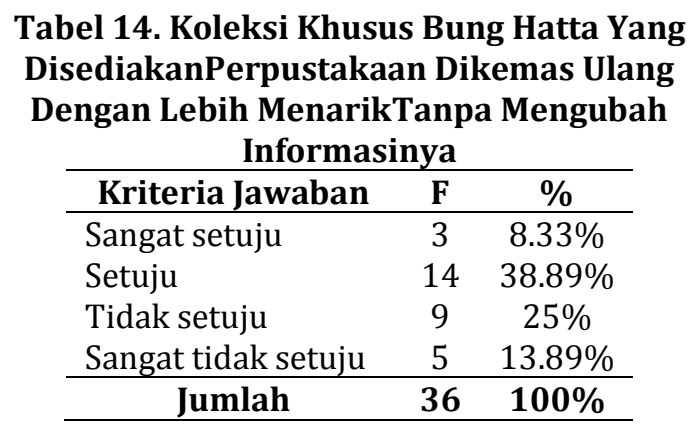

Menurut pengolahan data dengan dikemas ulang koleksi khusus Bung Hatta tanpa mengubah nilai informasinya dapat menarik pemustaka untuk memanfaatkan koleksi khusus Bung Hatta.Kemas ulang seperti mengubah koleksi audio Bung Hatta menjadikannya kedalam bentuk buku hal ini dilakukan untuk mempermudah akses pemustaka memanfaatkan koleksi.Jadi kemas ulang koleksi khusus Bung Hatta merupakan salah satu faktor yang menyebabkan koleksi khusus Bung Hatta di manfaatkan oleh pemustaka.

\section{Keterampilan Pustakawan dalam Melayani Pemustaka}

Keterampilan pustakawan merupakan ketepatan dalam melayani dan berinteraksi dengan pemustaka baik secara verbal maupun non verbal dalam memberikan informasi yang di butuhkan pemustaka.indikator keterampilan pustakawan dalam melayani pemustaka yaitu kemampuan berkomunikasi, kemampuan memahami kebutuhan pengguna, memiliki keterampilan informasi, keterampilan mengenai materi perpustakaan.

Tabel 15. Pustakawan Ramah Dalam Berkomunikasi DenganPemustaka

\begin{tabular}{lcc}
\hline \multicolumn{1}{c}{ Kriteria Jawaban } & F & \% \\
\hline Sangat setuju & 13 & $36.11 \%$ \\
Setuju & 10 & $27.78 \%$ \\
Tidak setuju & 13 & $36.11 \%$ \\
Sangat tidak setuju & 0 & - \\
\hline \multicolumn{1}{c}{ Jumlah } & $\mathbf{3 6}$ & $\mathbf{1 0 0 \%}$ \\
\hline
\end{tabular}

Dapat simpulkan kemampuan komunikasi pustakwan dalam melayani pemustaka ramah terhadap pemustaka sehingga dengan sikap pustakwan yang ramah dalam melayani pemustaka menunjukan kesan yang baik dan akan mempengaruhi pemustaka dalam memanfaatkan koleksi. Menurut Utomo (2013) secara langsung atau tidak langsung sikap pustakwan sangat berpengaruh penting bagi pemustaka.

Tabel 16. Pustakawan Membantu Pemustaka Menemukankoleksi Yang Dibutuhkan

\begin{tabular}{lcc}
\hline Kriteria Jawaban & F & \% \\
\hline Sangat setuju & 6 & $16.67 \%$ \\
Setuju & 8 & $22.22 \%$ \\
Tidak setuju & 13 & $36.11 \%$ \\
Sangat tidak setuju & 9 & $25 \%$ \\
\hline \multicolumn{1}{c}{ Jumlah } & $\mathbf{3 6}$ & $\mathbf{1 0 0 \%}$ \\
\hline
\end{tabular}

Dapat simpulkan bahwa pustakawan belum maksimal membantu pemustaka untuk menemukan koleksi yang dibutuhkan secara langsung atau tidak langsung sikap pustakwan terhadap pemustaka sangat berpengaruh penting terhadap pemustaka, hal ini tidak sejalan dengan ketentuan IFLA (2006) keterampilan yang harus dimiliki pustakawan salah satunya adalah pustakwan harus memiliki kemampuan untuk memahami kebutuhan pengguna. 
Tabel 17. Pustakawan Memiliki Pengetahuan Tentang Koleksi Khusus Bung Hatta

\begin{tabular}{lcc}
\hline Kriteria Jawaban & F & \% \\
\hline Sangat setuju & 5 & $13.89 \%$ \\
Setuju & 19 & $52.78 \%$ \\
Tidak setuju & 6 & $16.67 \%$ \\
Sangat tidak setuju & 6 & $16.67 \%$ \\
\hline \multicolumn{1}{c}{ Jumlah } & $\mathbf{3 6}$ & $\mathbf{1 0 0 \%}$ \\
\hline
\end{tabular}

Dapat simpulkan kemapuan atau pengetahuan yang dimiliki pustakawan di UPT Perpustakaan Proklamator Bung Hatta sesuai dengan ketentuan IFLA (2006) seorang pustakawan memiliki pengetahuan mengenai materi perpustakaan yang membentuk koleksi perpustkaan serta bagaimana mengaksesnya.

Tabel 18. Pustakawan Terampil Dalam Melayani Pemustaka

\begin{tabular}{lcc}
\hline \multicolumn{1}{c}{ Kriteria Jawaban } & F & $\mathbf{\%}$ \\
\hline Sangat setuju & 6 & $16.67 \%$ \\
Setuju & 10 & $22.22 \%$ \\
Tidak setuju & 13 & $36.11 \%$ \\
Sangat tidak setuju & 7 & $19.44 \%$ \\
\hline \multicolumn{1}{c}{ Jumlah } & $\mathbf{3 6}$ & $\mathbf{1 0 0 \%}$ \\
\hline
\end{tabular}

Dari perolehan pengolahan data, menurut (36.11\%) responden mengatakan pustakawan belum cukup terampil dalam melayani pemustaka, dapat dikatakan inilah salah satu faktor yang menyebabkan kunjungan pemustaka terhadap ruang koleksi khusus sedikit sehingga tidak banyak yang memanfaatkan koleksi khusus Bung Hatta.

\section{Ketersedian Temu Kembali Informasi}

Tabel 19. Katalog Yang Disediakan Perpustakaan Membantu pemustaka dalam temu kembali informasi

\begin{tabular}{lcc}
\hline \multicolumn{1}{c}{ Kriteria Jawaban } & F & \% \\
\hline Sangat setuju & 15 & $16.67 \%$ \\
Setuju & 20 & $22.22 \%$ \\
Tidak setuju & 1 & $36.11 \%$ \\
Sangat tidak setuju & 0 & - \\
\hline \multicolumn{1}{c}{ Jumlah } & $\mathbf{3 6}$ & $\mathbf{1 0 0 \%}$ \\
\hline
\end{tabular}

Dapat disimpulkan katalog yang disediakan perpustakan sudah dapat membantu pemustaka dalam temu kembali koleksi. Penelusuran informasi dilakukan untuk memudahkan pemustaka menemukan koleksi yang diinginkan alat yang digunkan UPT perpustakaan proklamator Bung Hatta yaitu berua katalog online yang disebut OPAC (Online Pubic Access Catalog).
Tabel 20. Fasilitas Temu Kembali Yang Ada Diperpustakaan Memudahkan Pemustaka Dalam Temu Kembali Koleksi Khusus Bung Hatta

\begin{tabular}{lcc}
\hline \multicolumn{1}{c}{ Kriteria Jawaban } & F & \% \\
\hline Sangat setuju & 13 & $36.11 \%$ \\
Setuju & 20 & $22.22 \%$ \\
Tidak setuju & 3 & $8.33 \%$ \\
Sangat tidak setuju & 0 & - \\
\hline \multicolumn{1}{c}{ Jumlah } & $\mathbf{3 6}$ & $\mathbf{1 0 0 \%}$ \\
\hline
\end{tabular}

Menurut data tabel 21 fasilitas temu kembali yang ada diperpustakaan memudahkan pemustaka dalam temu kembali koleksi khusus Bung Hatta 13 orang responden (36.11\%) menyatakan sangat setuju, 20 orang responden (56.66\%) setuju kemudian 3 orang responden $(8.33 \%)$ tidak setuju dan tidak ada responden yang menjawab sangat tidak setuju. jadi dapat disimpulkan fasilitas temu kembali yang disediakan perpustakaan memudahkan pemustaka dalam temu kembali fasiltas yang disediakan perpustakaan seperti OPAC (Online Pubic Access Catalog) dan satu unit komputer yang disediakan perpustakaan untuk tamu kembali koleksi khusus Bung Hatta.

Tabel 21. Penataan Koleksi Khusus Bung Hatta Sesuai Pada Tempatnya

\begin{tabular}{lcc}
\hline Kriteria Jawaban & F & \% \\
\hline Sangat setuju & 9 & $25 \%$ \\
Setuju & 16 & $44.44 \%$ \\
Tidak setuju & 11 & $30.56 \%$ \\
Sangat tidak setuju & 0 & \\
\hline \multicolumn{1}{c}{ Jumlah } & $\mathbf{3 6}$ & $\mathbf{1 0 0 \%}$ \\
\hline
\end{tabular}

Dari perolehan data tersebut $44.44 \%$ responden mengatakan penataan koleksi khusus lemari buku sudah sesuai pada tempatnya,penempatan koleksi yang sesuai pada tempatnya membatu pemustaka lebih cepat dan mudah menemukan koleksi yang dibutuhkan. Sementara itu sebagian kecil (30.56\%) responden tidak setuju dengan penataan koleksi sesuai pada tempatnya mungkin mereka tidak menemukan koleksi yang dibutuhkan pada tempat yang seharusnya atau tempatnya yang di tunjukan oleh katalog hal ini bisa saja terjadi ada beberapa pemustka yang setelah menggunakan koleksi mereka menempatkan koleksi pada sembarang tempat.

Dari hasil analisis diperoleh data-data terkait dengan kebutuhan pemustaka akan koleksi, kecenderungan motif pemustaka, minat pemustaka, keadaan koleksi khusus perpustakaan, sikap pustakawan saat melayani 
pemustaka serta fasilitas temu kembali informasi. Faktor internal yang mempengaruhi pemustaka untuk memanfaatkan koleksi khusus Bung Hatta yang pertama kebutuhan pengguna, yang melatarbelakangi pemustaka memanfaatkan koleksi khusus Bung Hatta yaitu untuk memenuhi kebutuhan kognitif mereka, kebutuhan kognitif disini berkaitan dengan memafaatkan koleksi untuk menambah informasi. Kedua, motif pengguna yang melatari pemustaka memanfaatkan koleksi khusus Bung Hatta adanya motif atau suatu dorongan memanfaatkan koleksi khusus Bung Hatta untuk menyelesaikan tugas dan penelitian para pemustaka. Ketiga, minat pengguna dalam pemanfaatkan koleksi khusus Bung Hatta, minat pemustaka yaitu untuk membaca koleksi khusus Bung Hatta.

\section{PENUTUP}

Bedasarkan pembahasan pada penelitian yang telah dilakukan mengenai pemanfaatan koleksi khusus Bung Hatta diperoleh simpulan sebagai berikut. Pertama faktor internal yang membuat pemustaka memanfaatkan koleksi khusus Bung Hatta karena adanya kebutuhan, motif dan minat. (1) faktor kebutuhan hampir seluruh responden memberikan respon yang setuju (86.11\%) koleksi khusus Bung Hatta dimanfaatkan pemustaka untuk memenuhi kebutuhan menambah informasi. (2) motif atau suatu dorongan yang melatarbelakangi pemustaka untuk memanfaatkan koleksi khusus Bung Hatta sebagian besar responden memberikan respon yang setuju (55.55\%) memanfaatkan koleksi khusus Bung Hatta untuk menyelesaikan tugas dan penelitian,. (3) minat pengguna memanfaatkan koleksi khusus Bung Hatta hampir seluruh responden memberikan respon setuju (94.45\%) untuk membaca koleksi khusus Bung Hatta.

\section{DAFTAR PUSTAKA}

Akikunto, S. 2006. Prosedur Penelitian suatu pendekatan praktik edisi

IFLA/UNESCO. (2006). Pedoman perpustakaan sekolah dalam http://www.Ifla.org/vii/sii/pubs/schoolguedelines.html. Tanggal 10 september 2020.

Istiawan, S. R. (2014). Pemanfaatan bahan Pustaka Pada Mahasiswa Di Perpustakaan Unversitas Katolik Widya Mandala Surabaya. Jurnal Universitas Airlangga 3(2) , 302-319.

Rifauddin, M. (2017). Keterampilan sosial pustakawan dalam memberikan pelayanan bermutu di perpustakaan. Khizanah al-Hikmah : Jurnal Ilmu Perpustakaan, Informasi, dan kearsipan, 5 (1) 102-112

Sumantri, S. 2001. Perilaku Organisasi. Universitas Padjadjaran. Bandung

Sutarno N.S.2006. Manajemen Perpustakaan.Jakarta: Sagung Seto

Yusup, P. M. (2013). Ilmu Informasi Komunikasi dan Kepustakaan. Jakarta: Bumi Aksara 